\title{
Kajian Kondisi Terumbu Karang dan Strategi Pengelolaannya di Pulau Panjang, Air Bangis, Kabupaten Pasaman Barat
}

\author{
Angreini Oktarina' ${ }^{1)}$, Eni Kamal'), dan Suparno ${ }^{2)}$ \\ ${ }^{1)}$ Program Studi Pengelolaan Sumberdaya Perairan, Pesisir dan Kelautan \\ Program Pascasarjana Universitas Bung Hatta \\ ${ }^{2}$ Program Studi Pengelolaan Sumberdaya Perairan, Pesisir dan Kelautan \\ Program Pascasarjana Universitas Bung Hatta \\ Jln. Sumatera, Ulak Karang Padang 25114
}

Diterima 18 -10 -2013 Disetujui 05 -02-2014

\begin{abstract}
Coral reef ecosystems are essential for the survival of marine life, but the presence of coral reef are declined and decayed. Methods used in this study was a survey method. To retrieve the condition of coral cover using the line intercept transect while to determine management strategies using SWOT analysis. The average percentage of coral cover in 8 point research stations at $50.10 \%$ are still in the good condition, which is in the north $3 \mathrm{~m}$ depth $53.51 \%$, north $7 \mathrm{~m}$ depth $68.14 \%$, east $3 \mathrm{~m}$ depth $93.29 \%$, east $7 \mathrm{~m}$ depth $15.93 \%$, south $3 \mathrm{~m}$ depth $75.17 \%$, south $7 \mathrm{~m}$ depth $20.53 \%$, west $3 \mathrm{~m}$ depth $41.50 \%$, and west $7 \mathrm{~m}$ depth $32.79 \%$. The strategies for coral reef ecosystem management, among others: 1) community-based management, 2) forming Kelompok Masyarakat Pengawas (Pokmaswas) institutions, 3) establish in Panjang Island as a marine conservation areas, 4) Ko-Management-based, 5) effort to improve the economy in order to support the increased knowledge of the importance of conservation and management of coral reef ecosystem.
\end{abstract}

Keywords: Coral Reef, Management, Panjang Island, Strategy

\begin{abstract}
ABSTRAK
Terumbu karang merupakan ekosistem yang penting bagi kelangsungan hidup biota laut tetapi keberadaan terumbu karang mengalami kemunduran dan kerusakan. Metode penelitian yang digunakan adalah metode survei. Pengambil data kondisi tutupan karang menggunakan line intercept transect sedangkan untuk menentukan strategi pengelolaannya menggunakan analisis SWOT. Rata-rata persentase tutupan karang di 8 titik stasiun penelitian sebesar 50,10\% masih dalam kondisi baik,

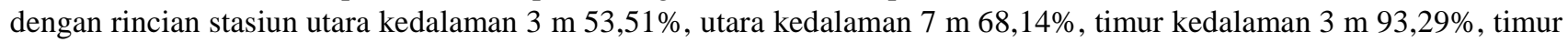

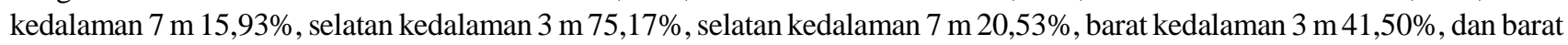
kedalaman $7 \mathrm{~m}$ 32,79\%. Strategi pengelolaan ekosistem terumbu karang di Pulau Panjang, antara lain: (1) pengelolaan berbasis masyarakat, (2) membentuk Kelompok Masyarakat Pengawas (Pokmaswas), (3) menetapkan kawasan perairan Pulau Panjang menjadi kawasan konservasi laut daerah, (4) pengelolaan berbasis Ko -Manajemen, dan (5) upaya peningkatan ekonomi dalam rangka menunjang peningkatan pengetahuan akan pentingnya pelestarian dan pengelolaan ekosistem terumbu karang.
\end{abstract}

Kata Kunci: Pengelolaan, Pulau Panjang, Strategi, Terumbu Karang

\footnotetext{
*Telp: +6282112460920

Email: angreini_oktarina@yahoo.com
} 


\section{PENDAHULUAN}

Ekosistem terumbu karang dan segala kehidupan yang terdapat di dalam laut merupakan salah satu sumber daya alam yang bernilai tinggi. Terumbu karang sebagai ekosistem esensial di perairan laut mempunyai peran sangat penting bagi kelangsungan hidup biota laut seperti ikan dan biota-biota lainnya. Pertumbuhan terumbu karang secara maksimum memerlukan perairan yang jernih, suhu yang hangat, gerakan gelombang, sirkulasi lancar, serta terhindar dari proses sedimentasi.

Keberadaan terumbu karang dari tahun ke tahun mengalami kemunduran, yaitu terjadi kerusakan yang mengkhawatirkan sehingga menimbulkan penyusutan dalam jumlah kuantitas dan kualitas. Kerusakan ekosistem terumbu karang tidak terlepas dari aktivitas manusia baik di daratan maupun pada ekosistem pesisir dan lautan.

Penelitian terbaru LIPI (2011) menyatakan 30,76\% terumbu karang Indonesia memiliki kondisi yang kurang baik atau rusak. Data yang dihimpun dari 1.076 stasiun pengamatan itu mengungkap hanya 5,58\% karang yang kondisinya sangat baik, $26,95 \%$ baik dan $36,90 \%$ sisanya cukup baik.

Kabupaten Pasaman Barat mempunyai potensi kawasan wilayah laut dan pesisir dan masih belum terkelola dengan maksimal. Pulau Panjang memiliki luas sekitar 220 $\mathrm{Ha}$, merupakan satu-satunya pulau yang dihuni oleh penduduk. Hasil survey yang dilakukan oleh DKP Propinsi Sumatera Barat (2011) didapatkan hasil pengukuran terumbu karang pada beberapa stasiun transek di perairan Pulau Panjang pada kondisi tutupan karang kategori rusak dengan kisaran tutupan rata-rata 16,8\%.

Mengingat besarnya ancaman terhadap terumbu karang dan ketergantungan masyarakat pesisir terhadap sumberdaya perikanan, maka diperlukan strategi pengelolaan ekosistem terumbu karang yang berkelanjutan. Penelitian ini bertujuan untuk menganalisis kondisi terumbu karang dan merumuskan strategi pengelolaan terumbu karang di Pulau Panjang, Air Bangis, Kabupaten Pasaman Barat.

\section{BAHAN DAN METODE}

Penelitian dilaksanakan selama 3 bulan dimulai dari bulan April hingga Juni 2013 berlokasi di Pulau Panjang,
Air Bangis, Kabupaten Pasaman Barat Provinsi Sumatera Barat. Metode yang digunakan adalah metode survei. Pengambilan data kondisi terumbu karang adalah dengan metode Line Intercept Transect (LIT) dilakukan di 4 (empat) stasiun sesuai dengan arah mata angin, yaitu Utara, Selatan, Timur, dan Barat dengan 2 (dua) kedalaman, yaitu kedalaman $3 \mathrm{~m}$ dan $7 \mathrm{~m}$ (Gambar 1). Panjang garis transek $10 \mathrm{~m}$ diulang sebanyak 3 kali pada garis pita (roll $\mathrm{m}$ ) sepanjang $50 \mathrm{~m}$ (English et al. 1997). Pengambilan data ikan karang berupa jenis (spesies) digunakan metode sensus transek sabuk (Belt Transect Census) (Brock 1982; English et al. 1997). yang dikondisikan dengan metode sensus visual. Parameter kualitas air (suhu, salinitas, $\mathrm{pH}$, DO, fosfat, nitrat, dan kecerahan) diamati pada tiap stasiun pengamatan. Dalam merumuskan strategi pengelolaan terumbu karang menggunakan analisis SWOT.

\section{HASIL DAN PEMBAHASAN}

Kualitas Perairan Pulau Panjang. Pertumbuhan karang dan penyebaran terumbu karang tergantung pada kondisi lingkungannya. Kondisi ini pada kenyataannya tidak selalu tetap, akan tetapi seringkali berubah karena adanya gangguan, baik yang berasal dari alam atau aktivitas manusia. Parameter kualitas perairan yang diukur dalam penelitian ini meliputi suhu, salinitas, $\mathrm{pH}$, DO, fosfat dan nitrat yang berkaitan secara langsung dengan ekosistem terumbu karang sebagai faktor pembatas bagi terumbu karang. Suhu merupakan faktor pembatas yang akan memberikan pengaruh besar terhadap kehidupan karang sehingga juga akan berdampak pada kehidupan hewan lain yang ikut berasosiasi bersama ekosistem terumbu karang. Hasil pengukuran suhu pada lokasi penelitian berkisar antara $28,7-30,6^{\circ} \mathrm{C}$. Supriharyono (2007) menjelaskan bahwa dalam kehidupan terumbu karang memiliki suhu kisaran untuk hidup antara $25-32^{\circ} \mathrm{C}$. Wells (1954) dan Kinsman (1964) menyatakan suhu yang optimal untuk pertumbuhan karang adalah pada kisaran $16-36^{\circ} \mathrm{C}$.

Salah satu permasalahan lingkungan yang terdapat di Pulau Panjang adalah tingginya sedimentasi yang berasal dari dua muara sungai, yaitu sungai Air Bangis dan Sungai Batang Tomak. Hal ini terlihat dari hasil pengamatan pada setiap lokasi penelitian tingkat kecerahan perairan Pulau Panjang berkisar antara 1-3 m, seperti Tabel 


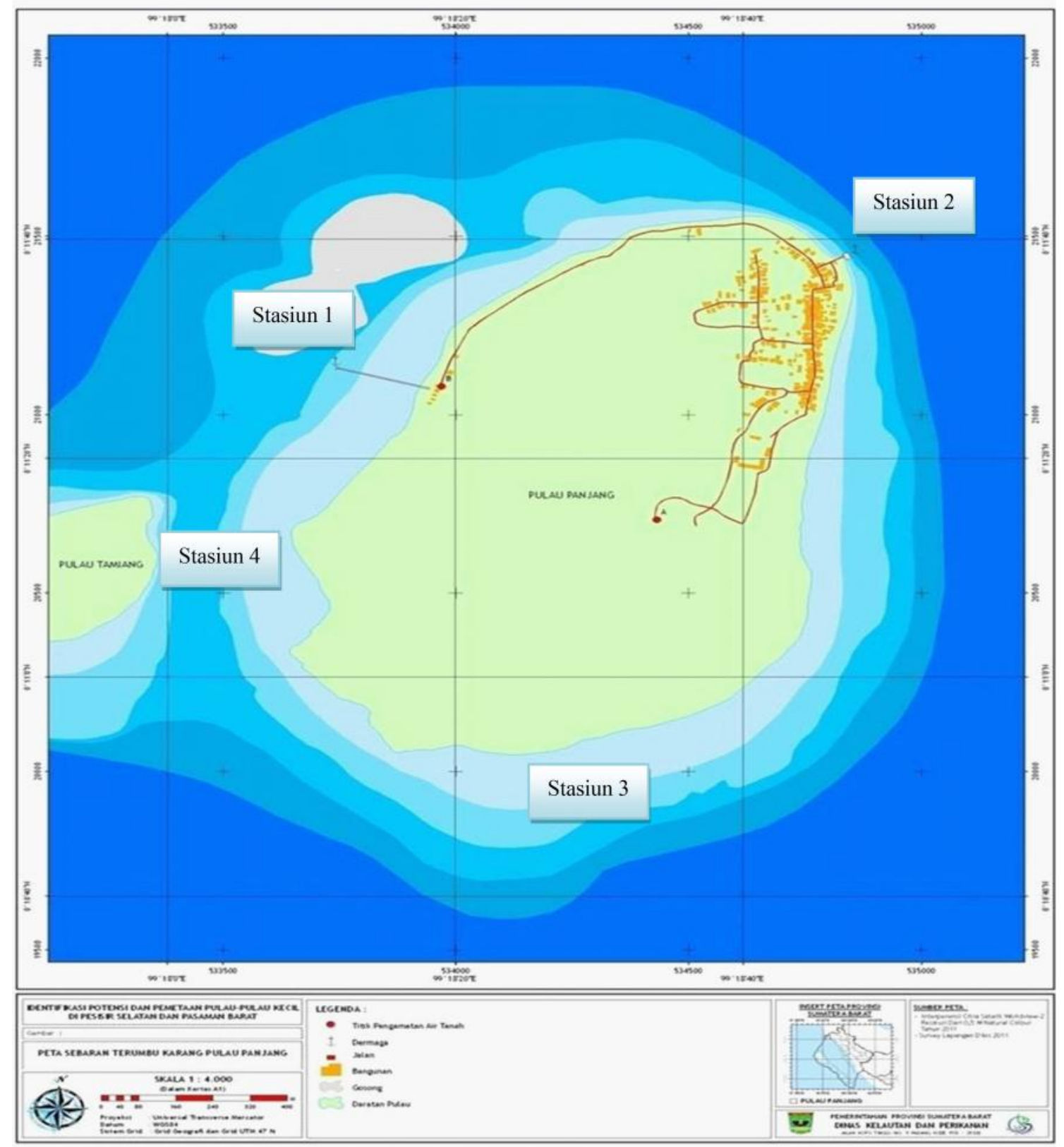

Gambar 1 Peta lokasi stasiun penelitian di pulau panjang

1. Apabila sedimen tersebut berukuran cukup besar dan banyak jumlahnya sehingga menutupi polyp (mulut) karang, sedangkan pengaruh langsung adalah melalui penetrasi cahaya dan banyaknya energi yang dikeluarkan oleh binatang karang untuk menghalau sedimen tersebut, yang berakibat turunnya laju pertumbuhan karang (Hubbard \& Pocock 1972; Pastorok \& Bilyard 1985).

Salinitas merupakan salah satu faktor pembatas kehidupan binatang karang. Hasil rata-rata pengukuran salinitas di lokasi penelitian adalah $30 \%$. Dahuri (2003) menjelaskan bahwa umumnya terumbu karang tumbuh dengan baik di wilayah dekat pesisir pada salinitas 30-35\%o.

Derajat keasaman $(\mathrm{pH})$ merupakan ukuran konsentrasi hidrogen dan ion hidroksida dalam larutan. Hasil pengukuran $\mathrm{pH}$ di lokasi penelitian berkisar antara 7,27-7,48. Pada umumnya $\mathrm{pH}$ air laut tidak banyak bervariasi, karena adanya sistem karbondioksida dalam air 
laut mempunyai kapasitas penyangga (buffering capacity) yang kuat. Ini berarti bahwa $\mathrm{pH}$ air laut tidak mudah mengalami perubahan. Salah satu tanda bahwa nilai $\mathrm{pH}$ terlalu tinggi atau terlalu rendah adalah banyaknya koral yang mati dan kerang yang membuka cangkangnya lebarlebar (Mismail 2010).

Hasil pengukuran DO di lokasi penelitian berkisar antara 6,79-7,23 mg/L. Salmin (2005) menyatakan oksigen memegang peranan penting sebagai indikator kualitas perairan, karena oksigen terlarut berperan dalam proses oksidasi dan reduksi bahan organik dan anorganik. Dalam kondisi anaerobik, peranan oksigen adalah untuk mengoksidasi bahan organik dan anorganik dengan hasil akhir adalah nutrien yang dapat menyuburkan perairan.

Fosfat merupakan bentuk fosfor yang dapat dimanfaatkan oleh tumbuhan. Fosfor dapat juga diartikan sebagai bahan makanan utama yang digunakan oleh semua organisme untuk pertumbuhan dan sumber energi. Hasil pengukuran kandungan fosfat di lokasi penelitian berkisar antara 3,21-4,68 mg/L. Senyawa fosfat dalam perairan Pulau Panjang berasal dari sumber alami seperti erosi tanah, buangan dari hewan dan pelapukan tumbuhan, dan dari laut itu sendiri. Tinggi rendahnya kandungan fosfat, nitrat dan zat total organik di suatu perairan selain tergantung kepada keadaan perairan juga tergantung pada musim (Muchtar 1999).

Hasil pengukuran kandungan nitrat di lokasi penelitian berkisar antara 0,09-0,27 mg/L. Hal ini dipengaruhi oleh aliran Sungai Batang Tomak dan Sungai Air Bangis yang membawa unsur hara dan bermuara di perairan Pulau Panjang. Sesuai dengan pernyataan Muchtar (1994) bahwa kandungan fosfat dan nitrat di suatu perairan dipengaruhi oleh aliran sungai yang membawa zat hara dan bermuara ke perairan tersebut.

\section{Kondisi Terumbu Karang Pulau Panjang. Ekosistem} terumbu karang (coral reef) merupakan ekosistem yang khas di daerah kepulauan khususnya di wilayah tropis. Hasil pengamatan terhadap tutupan terumbu karang di Pulau Panjang diketahui tipe terumbu karang di pulau ini yaitu tipe terumbu karang tepi (fringing reef) dengan lebar rataan terumbu karang bagian atas (reef flat) sekitar 200-400 m dari pantai kearah laut. Hasil pengamatan memperlihatkan, terumbu karang yang hidup didominasi oleh karang massive (berbentuk bongkahan), karang bercabang (coral branching) Acropora dan non Acropora, koral Foliose (berbentuk lembaran).

Pada kedalaman diatas $5 \mathrm{~m}$ populasi terumbu karang tidak banyak dijumpai, kondisi substrat dasar rata-rata berpasir dengan diselingi karang mati. Tabel 2. Presentase Tutupan Karang Hidup di Pulau Panjang Supriharyono (2002) menyatakan terdapat kecenderungan bahwa karang yang tumbuh atau beradaptasi pada perairan dengan sedimentasi tinggi bentuk pertumbuhannya akan mengarah kebentuk massive dan sub-massive.Persentase tutupan karang hidup bervariasi antara stasiun penelitian berkisar antara 15,93\% (kondisi rusak) di stasiun Pantai Timur kedalaman 7 meter sampai 93,29\% (kondisi sangat baik) di stasiun Pantai Timur kedalaman 3 meter. Rata-rata presentase tutupan karang hidup adalah 50,10\% (kondisi baik) (Tabel 2).

Pada stasiun pengamatan 1 (Utara), dengan posisi geografis $\mathrm{N} 00.19115^{\circ}, \mathrm{E} 099.30313^{\circ}$ titik pengamatan ke -1 pada kedalaman $3 \mathrm{~m}$ memperlihatkan total persentase tutupan karang hidup sebesar 53,51\%. Persentase karang

Tabel 1 Hasil pengukuran parameter kualitas perairan di pulau panjang

\begin{tabular}{|c|c|c|c|c|c|c|c|c|c|c|}
\hline \multirow{3}{*}{ Parameter } & \multirow{3}{*}{ Satuan } & \multicolumn{8}{|c|}{ Stasiun / Titik penelitian } & \multirow{3}{*}{$\begin{array}{l}\text { Baku } \\
\text { mutu* }\end{array}$} \\
\hline & & \multicolumn{2}{|c|}{1} & \multicolumn{2}{|c|}{2} & \multicolumn{2}{|c|}{3} & \multicolumn{2}{|c|}{4} & \\
\hline & & 1 & 2 & 1 & 2 & 1 & 2 & 1 & 2 & \\
\hline Suhu & ${ }^{\circ} \mathrm{C}$ & 29,3 & 29,1 & 28,7 & 28,2 & 30,6 & 30,1 & 29,8 & 29,4 & $28-30$ \\
\hline Salinitas & $\%$ & 30 & 30 & 30 & 30 & 30 & 30 & 30 & 30 & $33-34$ \\
\hline $\mathrm{pH}$ & - & 7,27 & 7,30 & 7,46 & 7,48 & 7,37 & 7,40 & 7,39 & 7,41 & $7-8,5$ \\
\hline DO & $\mathrm{mg} / \mathrm{L}$ & 7,21 & 7,23 & 6,79 & 6,82 & 7,04 & 7,09 & 6,8 & 6,9 & $>5$ \\
\hline Fosfat & $\mathrm{mg} / \mathrm{L}$ & 4,63 & 4,68 & 3,27 & 3,30 & 4,12 & 4,17 & 3,21 & 3,29 & 0,015 \\
\hline Nitrat & $\mathrm{mg} / \mathrm{L}$ & 0,23 & 0,27 & 0,09 & 0,15 & 0,13 & 0,18 & 0,12 & 0,20 & 0,008 \\
\hline Kecerahan & $\mathrm{m}$ & 1,5 & 1 & 1,5 & 1 & 3 & 2,5 & 1 & 1 & $>5$ \\
\hline
\end{tabular}


Acropora sebesar 20,64\% (Acropora Coral Branching (ACB) 18,07\% dan Acropora Coral Submassive (ACS) $2,57 \%)$.

Persentase karang non-Acropora sebesar $32,87 \%$ (Coral Massive (CM) 26,94\%, Coral Branching (CB) 2,71\% dan Coral Foliose (CF) 2,71\%). Titik pengamatan ke-2 pada kedalaman $7 \mathrm{~m}$ memperlihatkan total persentase tutupan karang hidup sebesar 68,14\%. Persentase karang Acropora sebesar 19,00\% (ACB 16,64\%, ACS 2,57\% dan Acropora Coral Encruisting (ACE) 0,79\%). Pada titik ini persentase tutupan karang hidup masih di dominasi oleh karang nonAcropora sebesar 49,14\% (CM 42,86\%, CB 0,79\%, Coral Encruisting (CE) 5,29\% dan Coral Mushroom (CMR) $0,21 \%$ ) dan tutupan substrat pasir (Sand) sebesar $12 \%$.

Pada stasiun pengamatan 2 (Timur), dengan posisi geografis $\mathrm{N} 00.19421^{\circ}$, E $009.30675^{\circ}$ titik pengamatan ke-1 pada kedalaman $3 \mathrm{~m}$ memperlihatkan total persentase tutupan karang hidup sebesar 93,29\%. Persentase karang Acropora sebesar 7,00\% (ACB 6,21\% dan ACS 0,79\%). Persentase tutupan karang hidup non -Acropora sebesar 86,29\% (CM 71,5\%, CB 4,93\%, CE 2,64\%, Coral Submassive (CS) $3,86 \%$, CF 2,00\% dan CMR 1,36\%). Pada titik pengamatan ke-2, pada kedalaman $7 \mathrm{~m}$, memperlihatkan total persentase tutupan karang hidup sebesar 15,93\%. Persentase karang Acropora sebesar 0,86\% (ACB 0,86\%). Persentase tutupan karang hidup masih di dominasi oleh karang non-Acropora sebesar 15,07\% (CM 8,71\%, CB 5,07\%, CE 0,86\% dan CMR 0,43\%) dan tutupan persentase substrat pasir (Sand) sebesar 73,14\%.

Pada stasiun pengamatan 3 pada sisi Selatan pulau, dengan posisi geografis $\mathrm{N} 00.18915^{\circ}$, E $099.31413^{\circ}$ titik pengamatan ke-1 pada kedalaman 3 memperlihatkan total persentase tutupan karang hidup sebesar $75,17 \%$.
Persentase karang Acropora sebesar 40,93\% (ACB 40,14\% dan Acropora Coral Tabulate (ACT) 0,79\%). Persentase tutupan karang hidup non-Acropora sebesar 34,24\% (CB 22,97\%, CE 8,96\%, CMR 2,03\% dan CS 0,29\%). Titik pengamatan ke-2 pada kedalaman $7 \mathrm{~m}$ memperlihatkan total persentase tutupan karang hidup sebesar $20,53 \%$. Persentase karang Acropora sebesar 6,07\% (ACB 5,36\% dan ACT 0,71\%). Persentase tutupan karang hidup nonAcropora sebesar 14,46\% (CB 11,21\%, CE 2,64\% dan CMR $0,60 \%$ ).

Pada stasiun pengamatan 4 sisi Barat pulau, dengan posisi geografis $\mathrm{N} 00.18579^{\circ}, \mathrm{E} 099.30083^{\circ}$ titik pengamatan ke -1 pada kedalaman 3 m memperlihatkan total persentase tutupan karang hidup sebesar 41,50\%. Persentase karang Acropora sebesar 3,50\% (ACB 0,86\%, ACT 1,57\%, ACE $0,14 \%$ dan ACS 0,93\%). Persentase tutupan karang hidup non-Acropora sebesar 38\% (CM 20,71\%, CB 7,36\%, CE $6,21 \%$, CF 1,36\% dan CMR 2,36\%). Pada titik pengamatan ke-2, pada kedalaman $7 \mathrm{~m}$, memperlihatkan total persentase tutupan karang hidup sebesar 32,79\%.

Persentase karang Acropora sebesar 0,79\% (ACB 0,79\%). Persentase tutupan karang hidup didominasi oleha karang non-Acropora sebesar 32\% (CM 21,21\%, CB 7,71\%, CE 2,64\% dan CMR 0,43\%). Mengacu pada Keputusan Menteri Lingkungan No. 24 Tahun 2001 Tentang Kriteria Baku Kerusakan Terumbu Karang, bahwa kondisi terumbu karang di perairan Pulau Panjang masih dalam kondisi baik, dengan persentase tutupan karang sebesar 50,10\%.

Ikan Karang Perairan Pulau Panjang. Secara keseluruhan di perairan Pulau Panjang frekuensi kehadiran didominasi oleh ikan mayor dari suku Pomacentridae terutama jenis ikan Pomacentrus moluccensis, Neopomacentrus azysron, dan Chrysiptera unimaculata.

Tabel 2 Presentase tutupan karang hidup di pulau panjang

\begin{tabular}{|c|c|c|c|}
\hline \multicolumn{2}{|c|}{ Stasiun } & Tutupan karang hidup (\%) & Kategori \\
\hline \multirow[t]{2}{*}{ Utara } & $3 \mathrm{~m}$ & 53,51 & Baik \\
\hline & $7 \mathrm{~m}$ & 68,14 & Baik \\
\hline \multirow[t]{2}{*}{ Timur } & $3 \mathrm{~m}$ & 93,29 & Sangat Baik \\
\hline & $7 \mathrm{~m}$ & 15,93 & Rusak \\
\hline \multirow[t]{2}{*}{ Selatan } & $3 \mathrm{~m}$ & 75,17 & Sangat Baik \\
\hline & $7 \mathrm{~m}$ & 20,53 & Rusak \\
\hline \multirow[t]{2}{*}{ Barat } & $3 \mathrm{~m}$ & 41,50 & Sedang \\
\hline & $7 \mathrm{~m}$ & 32,79 & Sedang \\
\hline \multicolumn{2}{|c|}{ Rata-Rata } & 50,10 & Baik \\
\hline
\end{tabular}


Kemudian dari suku Chaetodontidae jenis Chaetodon triangulum. Selain itu juga ditemukan ikan target dari suku Lutjanidae jenis Lutjanus decussates (Tabel 3).

Dari hasil pengamatan yang dilakukan untuk ikan karang, diketahui frekuensi kehadiran ikan karang yang mendominasi adalah suku Pomacentridae sebesar 100\%, terdiri dari jenis Pomacentrus moluccensis dan Neopomacentrus azysron masing-masing sebesar 100\% dan Chrysiptera unimaculata sebesar 87,5\% (Tabel 3). Hal ini dikarenakan karang mati terdapat di semua stasiun penelitian dengan rata-rata tutupan karang mati sebesar 17,73\%. Ikan karang suku Pomancentridae adalah salah satu kelompok ikan karang yang besar jumlahnya, mendiami perairan laut tropis yang umumnya tidak begitu dalam (Suharti 1990).

Kelompok ikan suku Pomacentridae hidup pada habitat yang sesuai dengan habitat anemon. Anemon hidup dengan melekatkan tubuhnya diantara cabangcabang karang (biasanya pada karang-karang yang sudah mati), di daerah dengan dasar berpasir atau berlumpur. Anemon sebagai host (tuan rumah) bagi ikan-ikan giru dapat dijumpai di daerah terumbu karang yang dangkal, di goba ataupun di lereng terumbu karang (Allen 1972; Dunn 1981).

Kemudian dari suku Chaetodontidae yaitu jenis Chaetodon triangulum sebesar 87,5\%, Chaetodontidae atau ikan kepe-kepe merupakan ikan karang sejati dan distribusinya hanya disekitar terumbu karang (Burges, 1978; Hutomo, 1986). Burges (1978) mempercayai bahwa akan dijumpai ikan kepe-kepe pada setiap komunitas terumbu karang dalam kondisi baik.

Dari suku Lutjanidae yaitu jenis Lutjanus decussates sebesar 75\%, Lutjanidae ditemukan di perairan tropis dan sering dikaitkan dengan habitat terumbu (Allen 1985).
Michelle et al. (2009) menemukan pada tujuh jenis terumbu karang yang dapat dimanfaatkan oleh ikan Lutjanidae. Kelompok ikan dari famili Lutjanidae pada umumnya menempati wilayah perairan dengan substrat sedikit berkarang dan banyak tertangkap pada kedalaman antara 40-70 m terutama untuk yang berukuran besar, ikan muda yang masih berukuran kecil biasa menempati daerah hutan bakau yang dangkal atau daerah-daerah yang banyak ditumbuhi oleh rumput laut (Widodo et al. 1991).

Adanya perbedaan komposisi ikan karang berdasarkan kelompok pada masing-masing stasiun penelitian selama pengamatan adalah merupakan gambaran variasi kondisi lingkungan habitatnya. Menurut Tamimi et al. (1993) bahwa distribusi spasial beberapa jenis ikan secara nyata dapat dideterminasi oleh karakteristik habitat tertentu. Karakteristik yang paling berperan dalam distribusi ini secara berurutan adalah arus, kecerahan, suhu air dan kedalaman. Disamping itu, terlindung atau tidaknya habitat merupakan salah satu faktor yang mempengaruhi pola distribusi spasial.

\section{Strategi Pengelolaan Terumbu Karang Pulau}

Panjang. Berdasarkan hasil identifikasi dan penilaian komponen SWOT yaitu faktor internal (kekuatan dan kelemahan) dan faktor eksternal (peluang dan ancaman) diperoleh strategi pengelolaan. Keterkaitan unsur-unsur tersebut adalah antara kekuatan dan peluang (SO), kekuatan dan ancaman (ST), kelemahan dan peluang (WO), dan antara kelemahan dan ancaman (WT) (Tabel 4). Setelah masing-masing unsur SWOT diberi bobot, unsur-unsur tersebut dihubungkan keterkaitannya untuk memperoleh strategi pengelolaannya. Nilai skor setiap alternatif strategi pengelolaan dijumlahkan untuk menentukan peringkat masing-masing strategi alternatif pengelolaan. Peringkat jumlah nilai skor tertinggi merupakan alternatif strategi alternatif kegiatan yang diprioritaskan pertama untuk

Tabel 3 Frekuensi kehadiran tertinggi ikan karang di pulau panjang

\begin{tabular}{llc}
\hline \multicolumn{1}{c}{ Jenis } & Kelompok & Frekuensi kehadiran (\%) \\
\hline & & 100 \\
Pomacentrus moluccenis & Mayor & 100 \\
Neopomacentrus azysron & Mayor & 87,5 \\
Chrysiptera unimaculata & Mayor & 87,5 \\
Chaetodon triangulum & Mayor & 75 \\
Lutjanus decussates & Target & \\
\hline
\end{tabular}




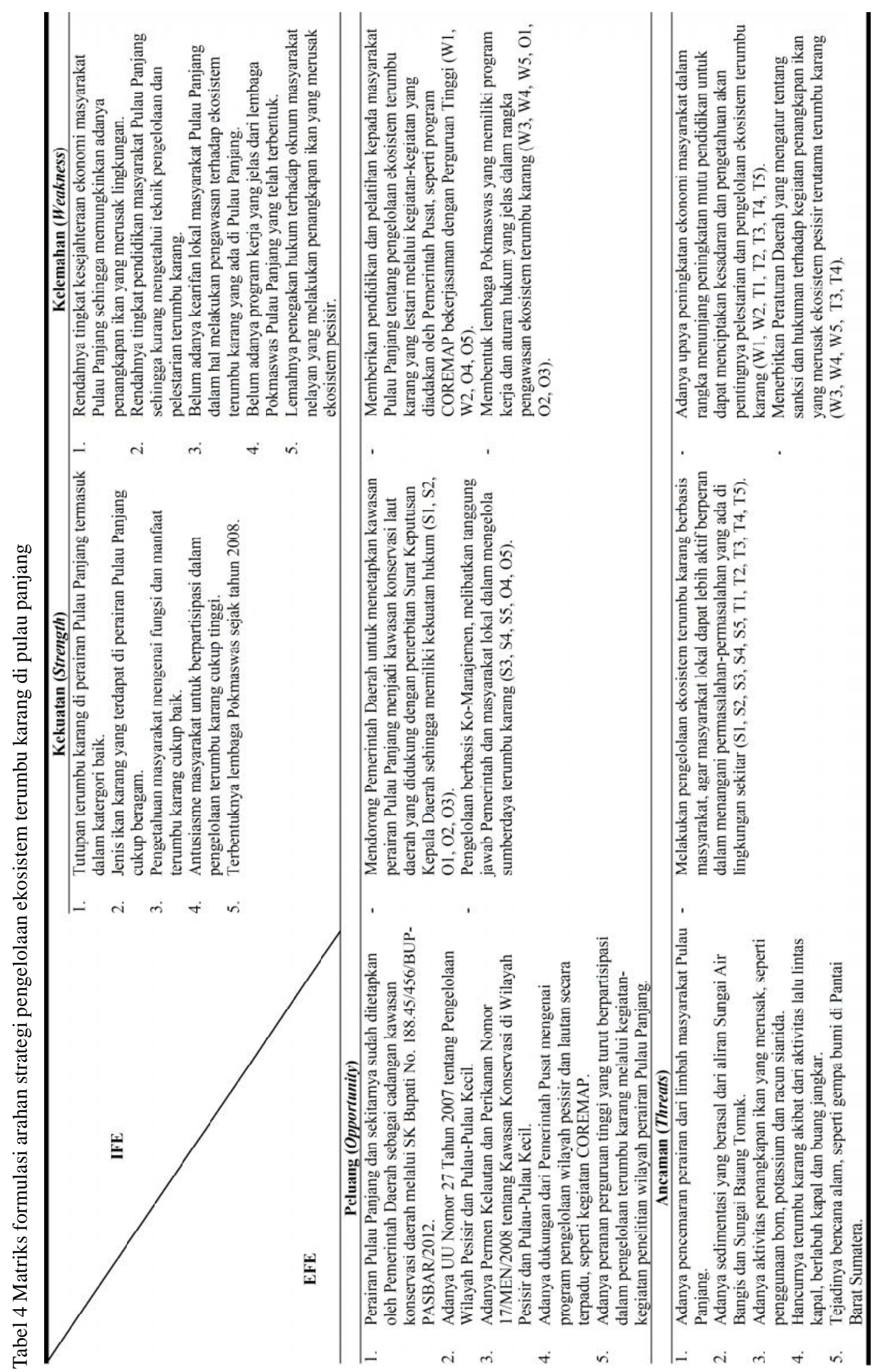


Tabel 5 Prioritas strategi pengelolaan ekosistem terumbu karang

\begin{tabular}{|c|c|c|c|}
\hline No & Unsur & Skor & Rank \\
\hline 1. & $\begin{array}{l}\text { Melakukan pengelolaan ekosisitem terumbu karang berbasis masyarakat, agar } \\
\text { masyarakat lokal dapat lebih aktif berperan dalam menangani permasalahan- } \\
\text { permasalahan yang ada di lingkungan sekitar. }\end{array}$ & 2,33 & 1 \\
\hline 2. & $\begin{array}{l}\text { Membentuk lembaga Pokmaswas yang memiliki program kerja dan aturan hukum } \\
\text { yang jelas dalam rangka pengawasan ekosistem terumbu karang. }\end{array}$ & 1,77 & 2 \\
\hline 3. & $\begin{array}{l}\text { Mendorong Pemerintah Daerah untuk menetapkan kawasan perairan Pulau Panjang } \\
\text { menjadi kawasan konservasi daerah yang didukug dengan penerbitan Surat Keputusan } \\
\text { Kepala Daerah sehingga memiliki kekuatan hukum. }\end{array}$ & 1,60 & 3 \\
\hline 4. & $\begin{array}{l}\text { Pengelolaan berbasis Ko-Manajemen, melibatkan tanggung jawab Pemerintah dan } \\
\text { masyarakat lokal dalam mengelola sumberdaya terumbu karang. }\end{array}$ & 1,49 & 4 \\
\hline 5. & $\begin{array}{l}\text { Adanya upaya peningkatan ekonomi masyarakat dalam rangka menunjang peningkatan } \\
\text { mutu pendidikan untuk dapat menciptakan kesadaran dan pengetahuan akan } \\
\text { pentingnya pelestarian dan pengelolaan ekosistem terumbu karang. }\end{array}$ & 1,42 & 5 \\
\hline 6. & $\begin{array}{l}\text { Memberikan pendidikan dan pelatihan kepada masyarakat Pulau Panjang tentang } \\
\text { pengelolaan ekosistem terumbu karang yang lestari yang melalui kegiatan-kegiatan } \\
\text { yang diadakan oleh Pemerintah Pusat, seperti program COREMAP bekerjasama } \\
\text { dengan Perguruan Tinggi. }\end{array}$ & 1,06 & 6 \\
\hline 7. & $\begin{array}{l}\text { Menerbitkan Peraturan Daerah yang mengatur tentang sanksi dan hukuman terhadap } \\
\text { kegiatan penangkapan ikan yang merusak ekosistem pesisir terutama terumbu karang. }\end{array}$ & 1,01 & 7 \\
\hline
\end{tabular}

dilaksanakan dalam pengelolaan terumbu karang dan diikuti oleh strategi alternatif berikutnya sesuai dengan peringkat jumlah nilai skor yang diperoleh (Tabel 5). Dari hasil analisa SWOT diperoleh prioritas strategi pengelolaan ekosistem terumbu karang di Pulau Panjang: 1) pengelolaan ekosistem terumbu karang berbasis masyarakat; 2) membentuk Kelompok Masyarakat Pengawas (Pokmaswas); 3) menetapkan kawasan perairan Pulau Panjang menjadi kawasan konservasi laut daerah; 4) pengelolaan berbasis Ko -Manajemen; 5) adanya upaya peningkatan ekonomi dalam rangka menunjang peningkatan pengetahuan akan pentingnya pelestarian dan pengelolaan ekosistem terumbu karang; 6) memberikan pendidikan dan pelatihan tentang pengelolaan ekosistem terumbu karang yang lestari, dan 7) menerbitkan Peraturan Daerah yang mengatur tentang sanksi dan hukuman terhadap kegiatan yang merusak ekosistem terumbu karang.

\section{SIMPULAN}

Hasil penelitian kondisi terumbu karang yang dilakukan di perairan Pulau Panjang diketahui dalam kondisi baik dengan rata-rata tutupan karang sebesar $50,10 \%$. Strategi pengelolaan ekosistem terumbu karang di Pulau Panjang: 1) pengelolaan berbasis masyarakat; 2) membentuk Kelompok Masyarakat Pengawas
(Pokmaswas); 3) menetapkan kawasan perairan Pulau Panjang menjadi kawasan konservasi laut daerah; 4) pengelolaan berbasis Ko-Manajemen; dan 5) upaya peningkatan ekonomi dalam rangka menunjang peningkatan pengetahuan akan pentingnya pelestarian dan pengelolaan ekosistem terumbu karang.

\section{UCAPAN TERIMA KASIH}

Penulis mengucapkan terima kasih kepada Bapak Bupati Pasaman Barat dan Kepala Dinas Kelautan dan Perikanan yang telah memberikan izin kepada penulis untuk melanjutkan pendidikan dan kepada seluruh masyarakat Pulau Panjang yang telah membantu penulis dalam memberikan informasi yang dibutuhkan.

\section{DAFTAR PUSTAKA}

Allen, G.R. 1972. The anemonefishes their classificaton and biology. T.F.H. Publications Inc. New Jersey. 288

Allen, G.R. 1985. Food and agriculture organization spesies catalogue. Snapper of the world VI, food and agriculture organization of the united nation rome.

Brock, R.E. 1982. A critique of the visual cencus method for assesing Cocral reef fish populations. Bulletin of Marine Science 32(1): 269-276.

Burges, W.E. 1978. Butterflyfishes of the World. Nepture City: T.F.H. Publication. 
Dahuri, R. 2003. Keanekaragaman Hayati Laut. PT. Gramedia Pustaka Utama. Jakarta.

Departemen Lingkungan Hidup. 2001. Kepmen Lingkungan Hidup No. 4 Tahun 2001. Kriteria Baku Kerusakan Terumbu Karang. Jakarta.

Dinas Kelautan dan Perikanan Propinsi Sumatera Barat. 2011. Laporan Akhir Identifikasi Potensi dan Pemetaan Pulau-Pulau Kecil di Pesisir Selatan dan Pasaman Barat. Padang.

Dunn, D.F. 1981. The Clownfish Sea Anemones: Stichodactylidae (Coelenterata: Actiniaria) and Other Sea Symbiotic with Pomacentrid Fishes. The American Philosophycal Society 71(1): 113 pp.

English, S., Wilkinson, C \& Baker, V. 1997. Survey Manual for Tropical Marine Resources. ASEANAustralia Marine Science Project: Living Coastal Resources, Australian Institut of Marine Science.

Hubbard, J.A.E.B \& Pocock, Y.P. 1972. Sediment rejection by recent sclerectian corals: A key to palaeoenvironmental reconstruction. Geol. Rdsc 61: 598626.

Hutomo, M. 1986. Coral Reef Fish Resources and Their Relation to Reef Condition: Some Case Studies in Indonesian Waters. Bogor: BIOTROP Special Publication No. 19

Kinsman, D.J.J. 1964. Reef coral tolerance of high temperatures and salinities. Nature 202: 1280-1282.

LIPI. 2011. Sepertiga terumbu karang di indonesia rusak. Liputan Media http://www.tempo.co/read/news/2012/ 10/31/061438910/Sepertiga Terumbu-Karang-diIndonesia-Rusak.

Michelle, R.H., Leanne, M.C., Ashley, J.W., Colin, A.S., Aaron, C.B \& Ann, L.P. 2009. The Comparative Biology of Lutjanid Species on the Great Barrier Reef. Fishing and Fisheries Research Centre School of Earth and Environmental Sciences James Cook University, Townsville. Supported by the Australian Government's Marine and Tropical Sciences Research Facility Project 4.8.3 Evaluation of the resiliency of key inter-reefal fish species.
Mismail, B. 2010. Akuarium Terumbu Karang. Cetakan Pertama. Malang: Universitas Brawijaya Press (UB Press).

Muchtar, M. 1994. Struktur Komunitas Biologi Padang Lamun di Pantai Selatan Lombok dan Kondisi Lingkungannya. Proyek Pengembangan Kelautan MREP 1993-1994. Jakarta: Pusat Penelitian dan Pengembangan Oseanologi-LIPI.

Muchtar, M. 1999. Fosfat, Nitrat dan Total Zat Organic Perairan Teluk Bayur dan Teluk Bungus, Sumatera Barat dan Hubungannya dengan Fitoplankton dan Bentos. ISBN 979-8105-68-0. Jakarta: Pusat Penelitian dan Pengembangan Oseanologi-LIPI.

Pastorok, R.A \& Bilyard, G.R. 1985. Effects of sewage pollution on coral reef communities. Mar. Ecol. Prog. Ser 21: 175-189.

Salmin. 2005. Oksigen terlarut dan kebutuhan oksigen biologi (BOD) sebagai salah satu indikator untuk menentukan kualitas perairan. Oseana 30(3): 21-26.

Suharti, S.R. 1990. Mengenal kehidupan kelompok ikan anemon (Pomacentridae). Oseana XV(4):135-145.

Supriharyono. 2002. Pelestarian dan Pengelolaan Sumberdaya Alam di Wilayah Pesisir Tropis. Jakarta: PT. Gramedia Pustaka Utama.

Supriharyono. 2007. Konservasi Ekosistem Sumberdaya Hayati di Wilayah Pesisir dan Laut Tropis. Pustaka Pelajar. Yogyakarta.

Tamimi, M.F., Soedharma, D., Butet, NA \& Bengen, D.G. 1993. Struktur komunitas dan distribusi ikan karang di periaran pulau sekapal dan pantai belebuh, lampung selatan dan hubungannya dengan karakteristik habitat. Jurnal Ilmu-Ilmu Perairan dan Perikanan Indonesia I(2): 27-43.

Wells, J.W. 1954. Recent corals of the marshall island. Prof. Pap. U.S. Geol. Surv 260(I): 385-486.

Widodo, J., et.al. 1991. Petunjuk Teknis (Pemanfaatan dan Pengelolaan Beberapa Spesies Sumberdaya Ikan Demersal Ekonomis Penting (Kakap Merah, Bawal Putih, Manyung dan Peperek). PHR/ KAN/PT.16/ 1991. Pusat penelitian dan Pengembangan Perikanan. 